\title{
Función de la célula $\beta$ después del embarazo, prevención de diabetes mellitus tipo 2, intervención en estilo de vida y/o farmacológica
}

Dra. Cristina Faingold

Servicio de Endocrinología, Unidad Asistencial Dr. César Milstein, Instituto

Cardiovascular de Buenos Aires, Ciudad Autónoma de Buenos Aires, Argentina

La diabetes gestacional (DG), definida como cualquier grado de intolerancia a la glucosa con inicio o primer reconocimiento durante el embarazo, se caracteriza por defectos maternos subyacentes en la respuesta de las células $\beta$ a la insulina durante el embarazo. Las mujeres con antecedentes de DG tienen un riesgo siete veces mayor de desarrollar DM posparto en comparación con aquellas sin DG.

Se han identificado varios factores de riesgo para la diabetes posparto, incluida la edad materna, los niveles de glucosa durante el embarazo, los antecedentes familiares de DM, el índice de masa corporal antes y después del parto, los patrones dietéticos, la actividad física y la lactancia. Estudios genéticos revelaron que la DG comparte variantes genéticas comunes con la DM2. Varios ensayos de intervención en el estilo de vida que tenían como objetivo mejorar los factores de riesgo modificables, incluida la dieta, el ejercicio y la lactancia materna, lograron reducir la incidencia de DM posparto, disminuir el peso y otras morbilidades relacionadas con la obesidad.

El Programa de Prevención de la Diabetes (DPP) es un ensayo representativo, intervencionista, aleatorizado, multicéntrico, que tenía como objetivo demostrar que las modificaciones intensivas del estilo de vida (IEV) o la metformina podrían prevenir el desarrollo de DM en hombres y mujeres de alto riesgo con intolerancia a la glucosa. Luego de 10 años de seguimiento, las mujeres con antecedentes de DG asignadas al placebo tenían un riesgo 48\% mayor de desarrollar DM en comparación con aquellas sin antecedentes de DG. En mujeres con antecedentes de DG, la IEV y la metformina redujeron la progresión a DM en comparación con el placebo en un 35 y un $40 \%$ respectivamente. Entre las mujeres sin antecedentes de DG, la IEV redujo la progresión a DM en un $30 \%$ y la metformina no redujo la progresión a diabetes. La presión arterial sistólica y diastólica y los niveles de triglicéridos también fueron más bajos en sujetos que se sometieron a modificaciones en el estilo de vida. La lactancia materna proporciona beneficios tanto a la madre como a su descendencia. La lactancia de más de tres meses redujo la DM posparto en un $46 \%$ en un estudio alemán. Otros estudios de intervención como el Troglitazone in Prevention of Diabetes (TRIPOD) y el Pioglitazone in Prevention of Diabetes (PIPOD) demostraron una tasa de incidencia de diabetes del $4,6 \%$ por año, que fue considerablemente más baja que la tasa de DM para el grupo placebo.

Aunque sabemos que la prevención de la DM es posible, en la práctica clínica, la pérdida en el seguimiento de las mujeres con DG después del parto es problemática. La mayoría de las mujeres con DG comprende la asociación entre DG y DM posparto, aún así no perciben el mayor riesgo que tienen de desarrollarla. Las tasas de reclasificación posparto oscilan entre el 19 y $73 \%$, que en general son bajas en comparación con las expectativas. 
Palabras clave: diabetes gestacional; prevención; posparto.

\section{Bibliografía}

- $\quad$ Moon $\mathrm{JH}$, et al. Prevention of type 2 diabetes mellitus in women with previous gestational diabetes mellitus. Korean J Intern Med 2017; 32:26-41

- $\quad$ Knowler WC, Barrett-Connor E, Fowler SE, et al. Reduction in the incidence of type 2 diabetes with lifestyle intervention or metformin. N Engl J Med 2002; 346:393-403.

- Diabetes Prevention Program Research Group, Knowler WC, Fowler SE, et al. 10-Year follow-up of diabetes incidence and weight loss in the Diabetes Prevention Program Outcomes Study. Lancet 2009; 374:1677-1686.

- $\quad$ Tanase-Nakao K, et al. Potential protective effect of lactation against incidence of type 2 diabetes mellitus in women with previous gestational diabetes mellitus: A systematic review and meta-analysis. Diabetes Metab Res Rev 2017; 33:e2875. 


\section{B cell function after pregnancy, prevention of T2D, lifestyle and / or pharmacological intervention}

Dr. Cristina Faingold

Endocrinology Service of the Dr. César Milstein Healthcare Unit, Cardiovascular Institute of Buenos Aires, Autonomous City of Buenos Aires, Argentina

Gestational diabetes mellitus (GDM), defined as any degree of glucose intolerance with onset or first recognition during pregnancy, is characterized by underlying maternal defects in the $\beta$-cell response to insulin during pregnancy.Women with a previous history of GDM have a greater than 7-fold higher risk of developing postpartum diabetes compared with women without GDM. Various risk factors for postpartum diabetes have been identified, including maternal age, glucose levels in pregnancy, family history of diabetes, pre-pregnancy and postpartum body mass index, dietary patterns, physical activity, and breastfeeding.Genetic studies revealed that GDM shares common genetic variants with type 2 diabetes.

A number of lifestyle interventional trials that aimed to ameliorate modificable risk factors, including diet, exercise, and breastfeeding, succeeded in reducing the incidence of postpartum diabetes, weight retention, and other obesity-related morbidities.

The Diabetes Prevention Program (DPP) is a representative multicenter randomized interventional trial that aimed to demonstrate that either intensive lifestyle(ILS) modifications or metformin could prevent the development of diabetes in high-risk men and women with impaired glucose tolerance. Over 10 years, women with a history of GDM assigned to placebo had a $48 \%$ higher risk of developing diabetes compared with women without a history of GDM. In women with a history of GDM, ILS and metformin reduced progression to diabetes compared with placebo by $35 \%$ and $40 \%$, respectively. Among women without a history of GDM, ILS reduced the progression to diabetes by $30 \%$, and metformin did not reduce the progression to diabetes. Systolic and diastolic blood pressure and triglyceride levels were also lower in subjects who underwent lifestyle modifications. Breastfeeding provides benefits to both the mother and her offspring. Breastfeeding $>3$ months reduced postpartum diabetes by $46 \%$ in a German study.Other interventios stydies like The Troglitazone in Prevention of Diabetes (TRIPOD) study and the Pioglitazone in Prevention of Diabetes (PIPOD) study demostrated anincidence rate of diabetes of $4.6 \%$ per year, which was considerably lower than the diabetes rate for the placebo group.

Although we know that prevention of diabetes is possible, in clinical practice, the loss of women with GDM to follow-up evaluations after delivery is problematic. The majority of women with GDM understand the association between GDM and postpartum diabetes but do not perceive themselves at increased risk of developing diabetes. Postpartum diabetes screening rates range from $19 \%$ to $73 \%$, which are generally poor compared with expectations.

Key words: gestational diabetes; prevention; postpartum.

\section{Bibliography}

- Moon $\mathrm{JH}$, et al. Prevention of type 2 diabetes mellitus in women with previous gestational diabetes mellitus. Korean J Intern Med 2017;32:26-41

Knowler WC, Barrett-Connor E, Fowler SE, et al. Reduction in the incidence of type 2 diabetes with lifestyle intervention or metformin. N Engl J Med 2002; 346:393-403. - Diabetes Prevention Program Research Group, Knowler WC, Fowler SE, et al. 10-Year follow-up of diabetes incidence and weight loss in the Diabetes Prevention Program Outcomes Study. Lancet 2009; 374:1677-1686. 
Revista de la Sociedad Argentina de Diabetes Vol. 55 № 3 Suplemento X Jornadas Nacionales de Diabetes - Septiembrediciembre de 2021. ISSN 0325-5247 (impresa) ISSN 2346-9420 (en línea)

- $\quad$ Tanase-Nakao et al., et al. Potential protective effect of lactation against incidence of type 2 diabetes mellitus in women with previous gestational diabetes mellitus: A systematic review and meta-analysis. Diabetes Metab Res Rev 2017;33:e2875. 